e ISSN-0976-7223 | Visit Us - www.researchjournal.co.in

DOI : 10.15740/HAS/IJAE/7.2/446-449

\title{
Physical properties of fresh and partially fermented coffee parchment
}

\section{SIDDHARTH AND A. KARTHIAYANI}

Received : 21.07.2014; Revised : 12.09.2014; Accepted : 23.09.2014

See end of the Paper for authors' affiliation

Correspondence to :

\section{SIDDHARTH}

College of Food and Dairy Technology, Koduvalli, CHENNAI (T.N.) INDIA

Email : siddharth_chennai@yahoo. co.in
- ABSTRACT : Physical properties of both fresh and partially fermented arabica coffee parchment of Cauvery variety viz., size, shape, angle of repose, bulk density, true density, porosity, 1000 parchment mass, hardness/crushing strength, adhering strength of mucilage to parchment and moisture content of washed parchment were studied. These data can be used for the development of machineries used in estate level processing of coffee parchment.

- KEY WORDS : Physical properties, Partially fermented coffee parchment, Arabica coffee

— HOW TO CITE THIS PAPER : Siddharth, M. and Karthiayani, A. (2014). Physical properties of fresh and partially fermented coffee parchment. Internat. J. Agric. Engg., 7(2) : 446-449. 